\title{
The Effect of Drug Types, Facility, and Infrastructure Against the Waiting Times at the Pharmacy Installation of Caruban General Hospital
}

\author{
Farid Amirudin ${ }^{1}$, Koesnadi ${ }^{2}$ \\ ${ }^{1}$ Doctor at the General Hospital, \\ Madiun District \\ ${ }^{2}$ IIK STRADA Indonesia
}

Email:

drg.faridamirudin@gmail.com

Received : March $3^{\text {th }} 2021$

Accepted : April 16 2021

Published : May $20^{\text {th }} 2021$

\begin{abstract}
Backgorund. Waiting time is one indicator of pharmacy service. The initial study with 5 patients in the pharmacy installation, of Caruban Hospital, concluded that all patients stated that they were tiring and queued for a long time. This study aims to examine whether there is an effect of type of drug, facility, and infrastructure to waiting time to get pharmacy service at Caruban Regional Public Hospital. The Design of this research used quantitative research The sampling technique was purposive sampling with total sample are 100 respondents. The statistical analysis used dummy regression. The average waiting time for pharmacy service is about 60 minutes for concocted drug, Average waiting time for packaged drugs is 46.5 minutes, and mixed drug is 69.5 minutes. 72 respondents stated that the infrastructure was in the good category and the rest said it was moderate. The results of the dummy regression analysis concluded that facilities and infrastructure had a significant effect simultaneously on the waiting time for services. The partial test results showed that the significance value for the facilities and infrastructure variable was 0.000 , and for the variable dosage forms in mixed prescriptions it had a significance value of 0.023 . The means variable is the variable that most influences the waiting time for the prescription service. The types of drugs in the prescription and waiting room infrastructure have a significant effect simultaneously on the length of queuing for drugs.
\end{abstract}

Keywords: Waiting time, drug types, facility, infrastructure

Copyright @ 2021 IIK STRADA Indonesia All right reserved.

This is an open-acces article distributed under the terms of the Creative Commons Attribution-ShareAlike 4.0 International License.

\section{INTRODUCTION}

The Pharmacy Installation is an inseparable part of the whole hospital health service system. Pharmacy service is a service that is responsible to patients related to pharmaceutical preparations with the aim of achieving definite results to improve the quality of life of patients (Minister of Health Regulation 72, 2016).

Pharmaceutical services has been regulated in the Minimum Service Standards for pharmaceutical services based on the Ministry of Health of the Republic Indonesia Policy. The Regulation set some standards of quality in pharmaceutical service such as waiting time for package drugs service is less than 30 minutes, concocted drugs $\leq 60$ minutes, there is no drug administration errors, customer satisfaction $\geq 80 \%$ and drug prescription writing based on $100 \%$ formulary.

The waiting time for drug services is divided into two, that are waiting time package drug services and the waiting time for concocted drug services. Based on Minister of Health Regulation 
number 58 at 2014, explain the definition about waiting time for package drug services and concocted drug services. Waiting time for non-concocted drug (package drug) services is the period start from patient submits the prescription until receive the drugs. Meanwhile, the waiting time for the concocted drug service is the period start from patient submits the prescription until receive the concocted drug. Waiting time is important indicator in pharmaceutical services. Waiting time will have an impact on patient satisfaction. This is supported by research which also resulted that there was a significant effect between waiting for drug taking on the satisfaction of outpatients at Puskemas, Lubuk Baja, Batam City. (Suherlina et all, 2018).

The Caruban Hospital Pharmacy Installation is a revenue center for the Hospital. The data shows that $51 \%$ of the revenue of Caruban Hospital is obtained from the pharmacy installatio. This condition is the basis so that the quality of drug service at the Pharmacy Installation needs to get attention and always be improved in patients satisfaction.

A preliminary study of 5 outpatients who have been received drug at the pharmacy installation,Four 4 people stated the wating time in the pharmacy service is to long and 1 person stated that the waiting time is not to long. For convenience indicator, only 1 person stated that the waiting room was comfortable and the rest said it was uncomfortable, and bored. For general services at the outpatient pharmacy installation, all patients stated that they were tired and waiting time is to long. Waiting time can be influence by some indicator like facility and infrastructure, type of drug and others. Based on the descriptions and preliminary studies, this study aims to examine whether there is an effect of the type of drug and the means on the length of queuing for drugs at the pharmacy installation at Caruban Hospital.

\section{METHODS}

This research is a descriptive analytical study using quantitative methods. This research was conducted from 2 until 7 november 2020. This study was conducted to obtain waiting time data for patient who get pharmaceutical services. This study was also conducted to obtain more in-depth information on matters related to what factors affect the length of time prescription outpatient services at the pharmacy installation.

The population in this study were all patients of Caruban Hospital from the outpatient clinic who received a prescription, and take drug in the pharmacy installion or drug depo. The sampling technique used purposive sampling technique. The inclusion criteria BPJS patients, coming from each outpatient clinic, patients at the outpatient drug dispatch, and queuing themselves at the outpatient pharmacy installation.

The instrument used in the study was a questionnaire that had passed through a process of validity and reliability testing. The validity and reliability tests were carried out at Aisyah Islamic Hospital in Madiun City. The independent variable in this study is the type of drug in the prescription and infrastructure. While the dependent variable is the length of the queue. The statistical analysis used is dummy regression analysis. The questionnaire also includes research ethics consisting of informed consent, using anonymity, and confidentiality.

\section{RESULTS}

The results of descriptive statistical analysis are presented in the tables below. Descriptive statistical analysis is used to explain the characteristics of respondents based on gender, age, level of education, occupation, type of insurance, infrastructure, and waiting time for services in pharmaceutical installations.

Tabel 1. Frequency Distribution based on Gender

\begin{tabular}{lcc}
\hline Sex & F & Percentage \\
\hline Male & 45 & 45.0 \\
Female & 55 & 55.0 \\
\hline Total & 100 & 100.0 \\
\hline
\end{tabular}

Table 1 provides information about the characteristics of respondents based on gender. Based on the information in the table, it is known that $55 \%$ of respondents or 55 people were female and the remaining 45 respondents were male. 
Tabel 2. Frequency Distribution based on Age

\begin{tabular}{lcc}
\hline Age & F & Percentage \\
\hline Teenager (17-25 years) & 3 & 3.0 \\
Adult (26-45 years) & 10 & 10.0 \\
Elderly (46-65 years) & 75 & 75.0 \\
Senior (65 -above) & 12 & 12.0 \\
\hline Total & 100 & 100.0 \\
\hline are categorized into adolescents, adults, seniors, and seniors. Based on the
\end{tabular}
information in table 2 above, it is known that 75 respondents are elderly (46-65 years). Meanwhile, there were 3 teenage respondents. Respondents who are elderly ( 65 years and over) are 12 patients. Meanwhile, respondents who were still teenagers (17-25 years) were 3 patients.

Tabel 3. Frequency Distribution based on Education

\begin{tabular}{lcc}
\hline Education & F & Percentage \\
\hline Junior High School or Elementar School & 63 & 63.0 \\
Senior High School & 24 & 24.0 \\
Diplome or Bachelor & 12 & 12.0 \\
Master or Doctor & 1 & 1.0 \\
\hline Total & 100 & 100.0
\end{tabular}

Table 3 provides information on the distribution of frequency by education level. Most of the respondents (about 63\%) have graduated from elementary school to junior high school. While the respondents with Magister or Doctor education was 1 person. Respondents who have an Bachelor degree education level are 12 respondents

Tabel 4. Frequency Distribution based on job

\begin{tabular}{lcc}
\hline Job & F & Percentage \\
\hline Labor or enterpreneur & 72 & 72.0 \\
Student or Employee & 3 & 3.0 \\
Housewife or other & 25 & 25.0 \\
\hline Total & 100 & 100.0 \\
\hline
\end{tabular}

Based on the information in table 4 above, the respondent's occupation is grouped into laborers / entrepreneurs, students or employees, and housewives or other. Respondents with jobs as laborers / enterpreneur were 72 people. While those who have jobs as students / employees are 3 people.

Tabel 5. Frequency Distribution based on insurance

\begin{tabular}{lcc}
\hline Assurance & F & Percentage \\
\hline PBI (Beneficiary of Contribution Assistance) & 90 & 90.0 \\
Non PBI & 10 & 10.0 \\
\hline
\end{tabular}

The types of insurance for respondents in this study are categorized into PBI and non-PBI. There were 90 respondents who were BPJS Kesehatan PBI patients and the remaining 10 respondents were in the non-PBI category.

Tabel 6. Frequency Distribution based on facility and infrastructure

\begin{tabular}{lcc}
\hline Facility and Infrastructure & F & Percentage \\
\hline Enough & 28 & 28.0 \\
Good & 72 & 72.0 \\
\hline Total & 100 & 100.0 \\
\hline
\end{tabular}

Infrastructure is a factor that can affect the length of service (waiting time). Based on table 6 above, it is known that 72 respondents stated that the infrastructure was in the good category. 
Tabel 7. Frequency Distribution based on waiting time.

\begin{tabular}{lc}
\hline Type dof drug & Long queue (minutes) \\
\hline Concocted & 60 \\
Package & 46,5 \\
Mixed (Concocted and package) & 69,5 \\
\hline
\end{tabular}

Table 7 provides information on the average waiting time for patients to receive pharmacy services. The average waiting time for concocted drugs is 60 minutes. Meanwhile, the average waiting time for packaged drugs was 46.5 minutes. The average waiting time for mixed drug services was 69.5 minutes.

Dummy regression analysis serves to determine the factors that affect the waiting time service. The regression analysis in this study was to examine the effect of the facility, infrastructure, the types of drugs which consisted of the large number of drugs in the prescription, the dosage forms in the prescription, and the drug classes simultaneously or partially. The results of dummy regression analysis for simultaneous testing are presented in Table 4.8 below.

Tabel 8. Dummy Regression Analysis

\begin{tabular}{lrrrrr}
\hline Model & Sum of Squares & df & Mean Square & F & \multicolumn{1}{c}{ Sig. } \\
\hline Regression & 34577.498 & 6 & 5762.916 & 8.445 & $.000^{\mathrm{b}}$ \\
Residual & 63461.012 & 93 & 682.376 & & \\
\hline Total & 98038.510 & 99 & & & \\
\hline
\end{tabular}

The simultaneous effect test serves to examine the effect of the variable facilities and infrastructure variables, the type of drug which consists of the number of drugs in the prescription, the dosage form in the prescription, and the drug class simultaneously. Significance value from the regression analysis for the simultaneous test of 0.000 . This value is smaller than the error rate used in the research $(\alpha)$, which is $0.05(5 \%)$. The conclusion that can be drawn from that value is the variable of the amount of the drug in the prescription, the form of the dosage in the prescription, and the class of the drug which simultaneously affect the waiting time.

Tabel 9. Partial Dummy Regression Analysis

\begin{tabular}{|c|c|c|c|c|c|c|}
\hline \multirow{2}{*}{\multicolumn{2}{|c|}{ Model }} & \multicolumn{2}{|c|}{$\begin{array}{l}\text { Unstandardized } \\
\text { Coefficients }\end{array}$} & \multirow{2}{*}{$\begin{array}{c}\text { Standardized } \\
\text { Coefficients } \\
\text { Beta } \\
\end{array}$} & \multirow[b]{2}{*}{$\mathrm{t}$} & \multirow[b]{2}{*}{ Sig. } \\
\hline & & $\mathrm{B}$ & Std. Error & & & \\
\hline \multirow[t]{8}{*}{1} & (Constant) & 169.093 & 26.893 & & 6.288 & .000 \\
\hline & Number of drugs & -3.022 & 4.777 & -.078 & -.633 & .529 \\
\hline & Facility and & -1.664 & .348 & -.462 & -4.777 & .000 \\
\hline & Infrastructre & & & & & \\
\hline & Concocted form & 13.144 & 19.035 & .059 & .690 & .492 \\
\hline & Mixed form & 14.520 & 6.273 & .228 & 2.315 & .023 \\
\hline & Certain drug & -6.640 & 11.053 & -.071 & -.601 & .550 \\
\hline & Repeated drug & 23.430 & 16.144 & .128 & 1.451 & .150 \\
\hline
\end{tabular}

Partial effect is conducted to examine whether each variable has a significant effect individually on waiting time. The partial test results show that the significance value for the facility and infrastructure variable was 0.000 , and for the variable dosage form in mixed prescriptions has a significance value of 0.023 .

The dummy regression model formed is y (waiting time) $=169.093-1.664$ facility and infrastructure +14.53 mixed drugs. The efficiency of the facility and infrastructure variable was 1.664. This value means that an increase in infrastructure and facility will have an impact on the waiting time service that is getting faster with a change of 1.664 times the unit. Meanwhile, the coefficient of dosage types in mixed form was 14,533 . This coefficient means that if the type of drug 
preparation is mixed (mix and pack), it will require a longer service time of 14.533 units compared to the length of service for the concoction drug.

The coefficient of determination is very useful to see the accuracy of the resulting regression model. The coefficient of determination can be seen from the adjusted R-Square value of the regression analysis

Tabel 10. Determination Coeficient

\begin{tabular}{|l|r|r|r|c|}
\hline Model & $\mathrm{R}$ & R Square & \multicolumn{1}{c|}{$\begin{array}{c}\text { Adjusted R } \\
\text { Square }\end{array}$} & $\begin{array}{c}\text { Std. Error of the } \\
\text { Estimate }\end{array}$ \\
\hline 1 & $.594^{\mathrm{a}}$ & .353 & .311 & 26.12234 \\
\hline
\end{tabular}

The Square-Adjusted $\mathrm{R}$ value generated from the regression analysis is 0.311 . This value means that the dummy regression model y (waiting time) $=169.093-1.664$ facility and infrastructure +14.53 mixed drugs can explain about $63.9 \%$ of the total diversity of existing data.

\section{DISCUSSION}

Respondents in this study consisted of 55\% women and $45 \%$ men. Most respondent in this study have age in the range of 45-65 years. This data is in accordance with the description of the health of the elderly in Indonesia that as they age, their physiological function decreases due to the degenerative process (aging) so that many non-communicable diseases appear in old age (Harpiani, 2020).

Table 4 provides information that 72 respondents have jobs as laborers / entrepreneurs. These results are consistent with the information in table 4.5 about the type of insurance used by patients. Most of the patients or about $90 \%$ used BPJS Health insurance in the PBI category. This condition related with table for that explained most respondents work as laborers/entrepreneurs fall into the category of poor people.

Facility and infrastructure is a factor that can affect to the waiting time for pharmacy services. In this research, Facility and infrastructure was categorized into less, medium, and good. Table 4.6 provides information that $72 \%$ of respondents stated that facility and infrastructure was in the good category. Good facilities will have an impact on patient satisfaction.

The waiting time for receive drug in pharmaceutical installaion was categorized into waiting time for recipe that conducted concoction drug, recipe that conducted packaged drug, and recipe that conducted drug and packaged drug.. The average waiting time for concocted drugs is 60 minutes, packaged drugs is 46.5 minutes, and mixed (concocted and packaged ) prescriptions are 69.5 minutes. Based on the minimum hospital service standards, pharmaceutical services for packaged drugs did not comply with standards because according to the regulations of the Ministry of Health, the waiting time for packaged prescription drug services was $\leq 30$ minutes. Long waiting times will also have an impact on patient satisfaction (Kastella, 2019).

The results above indicate that the waiting time for the concocted drugs is longer than the packaged drugs. The results of this study are in line with research conducted by Karuniawati et al in 2016 which also produced the same conclusion. Waiting time for concocted drug services also takes longer than package drug services because it requires more time in calculating drug doses, weighing medicinal ingredients, and carrying out the compounding process both in the form of capsule powder and other preparations.

Table 4.8 provides information that $72 \%$ of respondents stated that the Caruban Hospital infrastructure was in the good category. Good facilities will have an impact on patient satisfaction. These results are consistent with those carried out by Ristiani in 2017. The results of his research provide conclusions that the variable of health service infrastructure has a moderate effect on patient satisfaction but significantly affects patient satisfaction. It is possible that even though a health service institution is equipped with adequate infrastructure, but if it is not functioned as much as possible to serve patients, it will be less able to provide satisfaction to patients. Complete and functioning infrastructure and facilities will significantly support the achievement of patient satisfaction levels.

The results of statistical analysis with dummy regression in Table 8, provide the conclusion that facility, infrastructure and types of drugs have a significant effect simultaneously on waiting time in pharmaceutical services. The results of the partial regression analysis in table 9, has a conclusion that the infrastructure and infrastructure variable is the variable that most influences the length of the queue. In addition, the form of prescription drugs in the mixed form (concoted and package drug in one medical prescription) is also a variable that affects to waiting time.

The results of the regression analysis provide information that the better the facilities and infrastructure will affect to reduce waiting time in pharmaceutical services. This is supported by Fahrizal research in 2018. The results of his research conclude that the variable of infrastructure is a 
factor that affects the waiting time for patients at the pharmacy installation. Infrastructure facilities such as that the IFRS location is easily accessible, the availability of drug information and the availability of drug service flow instructions can accelerate service at the pharmacy installation can reduce the waiting time for patients to get prescription services. In his research, Fahrizal also mentioned that infrastructure such as Management Information System (MIS) will reduce waiting time and reduce the burden on officers.

The form of drug dosage in a mixture (packaged drug and concoction in one recipe), has an effect on the waiting time. This is because health workers have to prepare two types of drugs. The results of this study are in line with the research conducted by Prabasiwi et al in 2019. The results of their research conclude that one of the factors that influence waiting time is the number of drugs that must be made and the number of prescriptions that are received.

The Carubah Regional General Hospital must improve its facilities and infrastructure to reduce the waiting time for prescription services because prescription services for packaged drugs are still not up to standard. Some steps that can be taken are the use of a Management Information System (MIS). Using a MIS will speed up the prescription serving time. Increasing the number of pharmacy officers is also an effort that can be made to speed up services. In addition, increasing the knowledge and abilities of employees who work at IFRS must be improved to reduce the waiting time for prescription services (Toreh, 2020).

\section{CONCLUSION}

The results of dummy regression analysis showed that the types of drugs in the prescription and waiting room infrastructure and facility have a significant effect simultaneously on the waiting time to get drugs at the pharmacy installation. Based on the partial test, it was concluded that the type of drug used for mixed drugs and infrastructure had a significant effect on queuing time. The most dominant factor that affect to waiting time is the infrastructure and facility variable.

\section{ACKNOWLEDGMENTS}

The author is thankful for respondents for their valuable information and its awareness to participate in this research.

\section{CONFLICTS OF INTEREST:}

The author declares that they have no conflict of interest

\section{REFERENCES}

Fahrizal, H. M., Pamudji, G., Andayani T. M. 2018. Analisis Pelaksanaan Standar Pelayanan Minimal (SPM) Rumah Sakit Bidang Farmasi di Instalasi Farmasi Rumah Sakit Umum Daerah Muara Teweh Tahun 2016.

Harpiani, S., Puspitasari, C. E., Erwinayanti, G. A. P. S., Annisa, B.S. 2020 Analisis Tingkat Kepuasan Pasien Terhadap Kualitas Pelayanan di Instalasi Farmasi Rawat Jalan RSUD Provinsi NTB Periode Maret=April 2019. Sasambo Journal of Pharmacy.Vol. 1. No.1

Karuniawati, H., Hapsari, I. G., Arum M., Aurora, A. T., Wahyono, N. A. 2016. Evaluasi Pelaksanaan Standar Pelayanan Minimal (SPM) Farmasi Kategori Lama Waktu Tunggu Pelayanan Resep Pasien Rawat Jalan di RSUD Kota Salatiga. Kartika-Jurnal Ilmiah Farmasi. Vol.4., No.1

Kastella, N. A. F. 2019. Evaluasi Pelayanan Instalasi Farmasi Terhadap Waktu Tunggu Obat dan Kepuasan Pelanggan Ditinjau dari Kecepatan Pelayanan Resep di Rumah Sakit Bhayangkara Brimob tahun 2018.

Prabasiwi, A. Prabandari, S., Dewi, A., Nihlatuzzahroh, O. 2019. Waktu Tunggu Pelayanan Resep di dua Puskesmas Kabupaten Tegal. Parapemikir Jurnal Ilmiah Farmasi. Vol.8., No.1

Permenkes. 2014 : Standart Pelayanan Kefarmasian di rumah Sakit No.58

Permenkes. 2016 : Standart Pelayanan Kefarmasian di rumah Sakit No.72

Ristiani, I. Y. 2017. Pengaruh Sarana Prasarana dan Kualitas Pelayanan terhadap Kepuasan Pasien. Jurnal Coopetition. Vol. VII, No.2. Page 155-166. 
Suherlina, Nasution, S. W., Silaen, M., Suyono, T. 2018. Pengaruh Waktu Tunggu Pengambilan Obat Terhadap Kepuasan Pasien Rawat Jalan di Puskesmas Lubuk Baja Kota Batam Tahun 2018. Jurnal Mutiara Kesehatan Masyarakat. Vol. 3, No.2.

Toreh, E. S., Lolo, W. A., Datu, O. S. 2020. Evaluasi Pelaksanaan Standar Pelayanan Minimal (SPM) Farmaisi Kategori Lama Waktu tunggu Pelayanan Resep Pasien Rawat Jalan di Rumah Sakit Advent Manado. 